\title{
Research on the Guarantee Mechanism of Innovation and Entrepreneurship Education in Local Applied Undergraduate Universities*
}

\author{
Li Chen $^{1, * *}$ \\ ${ }^{I}$ Innovation and Entrepreneurship School of Xi'an Fanyi University, Xi'an, Shaanxi 710105, China \\ ${ }^{* *}$ Corresponding author. Email: chenli@xafy.edu.cn
}

\begin{abstract}
Although local applied undergraduate universities have launched innovation and entrepreneurship education, there are some prominent problems in innovation and entrepreneurship education, such as, vague understanding of innovation and entrepreneurship education, incomplete curriculum system for innovation and entrepreneurship education, lack of innovation and entrepreneurship education practice platforms, weak faculty, inadequate guidance and assistance for innovation and entrepreneurship education, etc. The article points out that the main problems are the ambiguous understanding of the objectives of innovation and entrepreneurship education and the imperfect development of the applied undergraduate universities. Based on the analysis of the objectives of innovation and entrepreneurship education, from the three main bodies of innovation and entrepreneurship education, the article proposes to build a guarantee mechanism which mainly includes management mechanism, curriculum system construction guarantee mechanism, teacher team guarantee mechanism, practice platform guarantee mechanism, practice training guarantee mechanism.
\end{abstract}

Keywords: Local applied undergraduate universities, Innovation and entrepreneurship education goals, Innovation and entrepreneurship education guarantee mechanism.

\section{INTRODUCTION}

In the middle of 21th century, a moderately prosperous society will be built in an all-round way in China and China will become a member of innovative countries. To accomplish this grand strategic goal, it is necessary to vigorously improve the innovation awareness and capabilities of the whole people. The Outline of the National Medium and Long-term Development Education Reform and Development Plan clearly requires that innovation and entrepreneurship education, as the foundation to build an innovative country, should be integrated into the entire process of talent training. The Ministry of Education requires all colleges and universities to set up innovation and entrepreneurship education courses from 2016. On

*Fund: 1. Innovation and Entrepreneurship Ecology and Youth Career Development Research Team

(No.XFU20KYTDC01); 2. Innovation and Entrepreneurship Teaching Team (No.T1909); 3.The Special Project of Xi'an

Social Science Fund: Private College Students Entrepreneurship

Education Problems and Countermeasures. (No.15XF01) the basis of characteristics of local universities, local applied undergraduate universities have responded to the call to vigorously carry out innovation and entrepreneurship education. These local universities combine with the advantages of disciplines to improve students' innovation and entrepreneurship knowledge, skills, awareness and spirit. Some achievements have been made in the construction of the practice platform and the transformation of results, since it is soon before local applied undergraduate universities launch innovation and entrepreneurship education. In the initial stage of experimentation, there are still some serious problems in the development process. Starting with the problems existing in the innovation and entrepreneurship education of local applied undergraduate universities, the article explores the establishment of a guarantee mechanism on the basis of exploring the orientation of the innovation and entrepreneurship education. 


\section{PROBLEMS IN THE DEVELOPMENT OF INNOVATION AND ENTREPRENEURSHIP EDUCATION}

\subsection{Vague understanding of Innovation and Entrepreneurship Education}

Although innovation and entrepreneurship courses, as public compulsory or alternative courses for students, have been opened in local applied undergraduate universities in response to the requirements of the Ministry of Education, there still exists a vague understanding of innovation and entrepreneurship education. In some universities, both leaders and teachers think that innovation and entrepreneurship courses, as supplementary courses to solve the employment difficulties. They are not sufficient for the necessity and importance of innovation and entrepreneurship education. The teachers are not willing to spend time and energy on in-depth research just to complete the teaching work. Most students, without interest in innovation and entrepreneurship courses, lack planning for career development and future life, for they are only satisfied with finding a job after graduation. Meanwhile, some students think that courses are meaningless, far away from them, and have little effect to earn credits. Above all, these thoughts and ideas reflect the vague understanding and indifference on innovation and entrepreneurship education.

\subsection{The Imperfect Curriculum System in Innovation and Entrepreneurship Education}

Innovation and entrepreneurship education, as a basic part of university education, is the foundation for students to carry out innovation and entrepreneurship training and practical activities. Local applied undergraduate universities have already offered some innovation and entrepreneurship education courses, but in the curriculum system, there are inclusive and main entrepreneurship basic courses, and there are few courses that integrate professional education and entrepreneurship education. In the second classroom, entrepreneurship propaganda, entrepreneurship consulting, entrepreneurship lectures, etc., are not even included in the teaching plan. Teachers teaching professional courses, know little about innovation and entrepreneurship courses, and seldom participate in teaching of professional courses. There is little connection between the innovation and entrepreneurship education courses offered and the core courses of each major in terms of teaching objectives and content. In the teaching process, although the case stories are typical, they are superficial, and they are not sufficiently digging into the cases. Entrepreneurial, domestic, and nationalized cases are not sufficiently developed for modern university students.

\subsection{Lack of Practice Platform in Innovation and Entrepreneurship Education}

Innovation and entrepreneurship education, different from general education, requires very high practicality. Undergraduates ought to rely on science technology centers, practice bases, and entrepreneurial incubators, and devote themselves to entrepreneurial practice and continuously to improve their basic entrepreneurial skills. On the one hand, local applied undergraduate universities have limited funds for running universities, and they invest less in physical business incubators and business incubators with capital, space, personnel, and policy inputs. Even some universities have no business incubators. On the other hand, enterprises are unwilling to participate in the practice of innovation and entrepreneurship education. These reasons lead to the deficiency of entrepreneurial practice platforms for local applied undergraduate universities. In some local applied undergraduate universities, the practice of innovation and entrepreneurship is often replaced by the completion of an entrepreneurial plan because there are no enough entrepreneurship practice chances. Most students do not have the opportunity to participate in entrepreneurial practice, and cannot empathize with the actual problems that may be encountered in the process of entrepreneurship, so there is no way to train and improve their ability to solve the problems.

\subsection{Weak Faculty in Innovation and Entrepreneurship Education}

Innovation and entrepreneurship education requires highly qualified teachers with rich knowledge for its comprehension, but there is weak faculty in local applied undergraduate universities for short development time, various subjective and objective constraints. At the same time, there is a serious shortage of full-time teachers and researchers in innovation and entrepreneurship 
education. In most universities, the teachers who teach innovation and entrepreneurship courses are part-time teachers whose major is economics, or who are engaged in teaching management, or college counselors. Most teachers don't carry out or participated in entrepreneurial practice at all for their simple experience of "out of school" after graduation to "entry into school" at work, so they have no any experience in a company. The Innovation and Entrepreneurship Course is so comprehensive that some teachers who lack of teaching skills and targeted and effective teaching methods. In order to make up for the lack of practical experience of teachers, some local applied universities have also invited some successful entrepreneurs to deliver lectures for students, but some entrepreneurs, without teaching experience, need to improve their teaching effect. In fact, there are many concrete problems to solve, and there is long way to go to form a long-term mechanism.

\subsection{Inadequate Guidance and Assistance in Innovation and Entrepreneurship Education}

At present, local applied undergraduate universities are unable to provide good services and assistance to students in investment, entrepreneurial funds, and incubation of entrepreneurial projects. In the process to carry out innovation and entrepreneurship education, some students actively participate in entrepreneurship practice, form their own entrepreneurial team, and even start a company or enterprise. However, students who lack practical experience, social experience, and social resource support will always meet various difficulties and problems in the course of their business development. It is necessary for universities to provide professional knowledge, encouragement, and teachers' support and guidance. These problems are closely related to not only the unclear orientation of the innovation and entrepreneurship education but the ineffective development of innovation and entrepreneurship education in local applied undergraduate universities.

\section{EDUCATIONAL GOALS OF INNOVATION AND ENTREPRENEURSHIP EDUCATION IN LOCAL APPLIED UNDERGRADUATE UNIVERSITIES}

Although innovation and entrepreneurship education courses have been carried out for nearly 20 years, the entrepreneurial participation rate of students is very low both in the first pilot universities and in the local applied undergraduate universities. The entrepreneurial success rate is not optimistic and so low when compared with developed countries in Europe and America. This situation is also far from our expectations for innovation and entrepreneurship education. This phenomenon are worthy of our deep consideration. Is the innovation and entrepreneurship education support not strong? Not practical? Is there a deviation in our innovation and entrepreneurship education orientation? What kind of innovation and entrepreneurship education do universities need? Should innovation and entrepreneurship education have levels?

The goal of innovation and entrepreneurship education, as the basic starting point and ultimate object, is a concrete manifestation that innovation and entrepreneurship education obtains the expected results. If goals of the innovation and entrepreneurship education are unclear, innovation and entrepreneurship education will fall into a blindly obedient situation, and will not know what to do during the development process. The innovation and entrepreneurship education goals should be based on the characteristics and reality of the university, combined with its students' reality, teacher level, teaching status, school conditions, facilities, equipment conditions and other comprehensive factors, and establish university characteristic target system on the base of presentable curriculum goals and teaching objects. The main responsibilities of local applied undergraduate universities are to train a large number of urgently needed, multi-category and diversified high-level applied talents for the local area to meet the needs of social and economic development in accordance with the principle of "social needs, market (employment) orientation, moral education first, and ability-based comprehensive development". The "locality" and "application-oriented" of local applied undergraduate universities determine that their innovation and entrepreneurship education 
development must establish their own characteristics, and actively integrate into the local economic and social development, so that the training of talents can meet the need of the local economy and society.

Innovation and entrepreneurship is a comprehensive social activity that requires entrepreneurs to have high requirements on their professional background, skill level, social resources, market experience, and comprehensive knowledge. The vast majority of students follow the path of growth that has been studying in school with a little social experience and understanding of society, and rarer resources. They have compared with students from first-class universities, students from local applied undergraduate universities have less knowledge accumulation, poorer professional depth and breadth so that many factors are not conducive to students' innovation and entrepreneurship. The faculty of innovation and entrepreneurship are weak in local applied undergraduate universities. Teachers can only teach students some principled entrepreneurial skills due to their own level and resource constraints, but these skills are not helpful in solving the difficulties and problems in students' entrepreneurial practice.

"Not everyone can start a business, but everyone needs entrepreneurial spirit." so, every student in a local applied universities should receive employment-based entrepreneurial education. Employment-based entrepreneurship has two meanings: one is to get a job first, then to start a business; the other is to start a business in a job. [1] Get employment first, then start a business. After graduation, students first choose a job according to their own majors and interests, familiarize themselves with the industry, accumulate work experience and resources, and then choose to be independent at the right time. Entrepreneurship on the job means that after graduation, students work diligently, enterprisingly, innovate in their own companies, organize their own teams, overcome difficulties, and strive to develop new businesses and new markets. The core purposes of employment-based entrepreneurship in local applied undergraduate universities are to cultivate and improve students, "innovative and entrepreneurial qualities", so that students are aware of innovation and entrepreneurship, the necessary professional abilities and strong practical abilities to promote their employment.

\section{CONSTRUCTION OF A GUARANTEE MECHANISM FOR INNOVATION AND ENTREPRENEURSHIP EDUCATION}

The basic prerequisite to understand the guarantee mechanism of innovation and entrepreneurship is to correctly understand the connotation of "innovation and entrepreneurship education in local applied undergraduate universities" and "guarantee mechanism". Mechanism, whose functions include incentive mechanism, restriction mechanism and guarantee mechanism, refers to the structural relationship and operation mode between various elements. Guarantee mechanism is the process and method of interaction between organizations or parts of a work system. In other words, it is a series of material and spiritual measures to aim at maintaining the good operation. The guarantee mechanism of innovation and entrepreneurship education in universities is to achieve the training goals of innovation and entrepreneurship education, to ensure the quality of innovation and entrepreneurship education, to make plans for the internal and external resources of university, and to rely on necessary organizations to strictly manage a series of quality management activities related to innovation and entrepreneurship education in university, so it forms the structure and operating mechanism to guarantee the quality of the innovation and entrepreneurship education.

Local applied undergraduate universities should take universities, teachers and students as the starting point when constructing a guarantee mechanism for innovation and entrepreneurship education because universities, teachers, and students are the main body and the most critical factors influencing innovation and entrepreneurship education

\subsection{Management Guarantee Mechanism of Innovation and Entrepreneurship Education}

Local applied undergraduate universities should further clarify the goals of innovation and entrepreneurship education, that is, to carry out "employment-based" entrepreneurship education and build an integrated management system for innovation and entrepreneurship education. Firstly, Local applied undergraduate universities should pay attention to innovation and entrepreneurship education, integrate university resources, 
comprehensively revise talent training programs, integrate innovation and entrepreneurship education into the entire process of talent training, emphasize the cultivation of college students' innovative spirit, entrepreneurial awareness, and innovation and entrepreneurship capabilities, actively promote the integration of professional education and innovation and entrepreneurship education and manage to build a platform for innovation and entrepreneurship education practice. Secondly, Local applied undergraduate universities should establish related systems, straighten out the entrepreneurship education management system, improve training system, and make the innovation and entrepreneurship education management system operate efficiently.

\subsection{Guarantee Mechanism of Innovation and Entrepreneurship Education Curriculum System}

A curriculum system should be constructed for innovation and entrepreneurship education according to the goals of innovation and entrepreneurship education in local applied undergraduate universities. On the one hand, local applied undergraduate universities ought to strengthen the cultivation of students' entrepreneurial awareness, build an innovative and entrepreneurial curriculum system that is conducive to student employment, and carry out the cultivation of entrepreneurial awareness throughout the four years of university study. Firstly, freshmen "career planning" course is to teach students to fully understand themselves, to strive to cultivate their own exploration spirit and to cultivate entrepreneurial personality qualities. Secondly, freshmen must fully understand the society, position themselves in life and clarify their career direction. Thirdly, freshmen must fully understand their majors and form a positive and healthy professional attitude, so as to improve their entrepreneurial awareness and trigger their entrepreneurial behavior. Fourthly, local applied universities should strengthen general education in entrepreneurship to carry out "foundation of entrepreneurship" courses for sophomores and juniors. Through course teaching, entrepreneurship knowledge is integrated into professional learning, so that students can understand entrepreneurshiprelated knowledge, policies, regulations to master professional knowledge, cultivate their entrepreneurship thinking and awareness, improve professional learning interest and cultivate and exercise entrepreneurial skills in extracurricular practice. Finally, in the year "Employment Guidance" class, seniors are taught to recognize the employment situation, clarify employment positioning, and universities provide targeted guidance to students who are willing to achieve employment through entrepreneurship in the future. On the other hand, local applied undergraduate universities should build a batch of innovative and entrepreneurial courses that integrate specialization and innovation. Firstly, it is necessary to closely integrate the needs of social and local economic construction, adjust majors settings, highlight practical ability, application knowledge and skills training, pay attention to professional skills and vocational quality education, focus on practical training and practical facilities and environmental construction, and developing practical capabilities. Secondly, local applied undergraduate universities should tap and enrich the innovation and entrepreneurship education resources of various professional courses, strengthen innovation and entrepreneurship education in the process of imparting professional knowledge, and promote integration of professional education and innovation and entrepreneurship education.

\subsection{Guarantee Mechanism of Facility Construction in Innovative and Entrepreneurial Education}

It is necessary for local applied undergraduate universities to strengthen the facility construction. Such as, training the facility to engage in innovation and entrepreneurship education and research, strengthening the training of "dual teachers and dual abilities" teachers, building a team of teachers suitable for innovation and entrepreneurship education, and setting up an innovation and entrepreneurship tutor bank. On the one hand, local applied undergraduate universities require teachers to participate in various types of related entrepreneurship guidance training and learning, improve teachers' teaching ability and skills, establish a system for teachers to work in industry enterprises, changing teachers' education concepts, optimizing knowledge structure, improving innovation and entrepreneurship education ability, improving teacher performance evaluation standards and methods, and strengthening the evaluation and evaluation of innovation and entrepreneurship education. On the other hand, local applied undergraduate universities, through a variety of chances, hire instructors for innovation and entrepreneurship education practice, and then long-term effective contact system is 
established to meet the needs of students for innovation and entrepreneurship education practice guidance.

\subsection{Guarantee Mechanism of Practice Platform Construction of Innovation and Entrepreneurship Education}

Local applied undergraduate universities should build innovation and entrepreneurship education practice platform. On the one hand, by actively applying for national entrepreneurship-related training and service bases, local applied undergraduate universities should encourage students to participate in relevant innovation and entrepreneurship training to strengthen connections with national-level creation spaces, provincial-level entrepreneurship training designated institutions, and certificates of entrepreneurship training. At the same time, universities should manage to establish a entrepreneurship incubation base to provide a place for innovation and entrepreneurship education and practical activities for all students, to give full play to the role of experimental training venues, to advocate the opening of laboratories to students, to open laboratory training projects, and to improve students' practical abilities. Local applied undergraduate universities should provide social innovation and entrepreneurship education practice on platform. Local applied undergraduate universities are to actively connect with social resources and realize the exchange mechanism for entrepreneurial projects. Then, they should establish entrepreneurship alliances with corporate institutions and units to unite provincial, municipal, and district-level entrepreneurial resources to serve young students' entrepreneurial employment, sign cooperation agreements with enterprises to jointly build innovation and entrepreneurship training bases, pay attention to government-schoolenterprise cooperation, and provide students with more practical internship opportunities.

\subsection{Practice Training Guarantee Mechanism Innovation and Entrepreneurship Education}

It is necessary to ensure that students can actively participate in practical training so as to make great progress in innovation and entrepreneurship education. Local applied undergraduate universities should rely on practical training projects to comprehensively improve students' innovation and entrepreneurship capabilities, and establish a long-term mechanism to support innovation and entrepreneurship competitions and special competitions in the practice of innovation and entrepreneurship education. Meanwhile, Local applied undergraduate universities promote the implementation of national and provincial-level innovative experimental programs for students, strive to build a complete education mechanism for the "college students' innovation and entrepreneurship program training program", encourage students to participate in college students' innovation and entrepreneurship training projects, participate in various discipline competitions at all levels and innovation and entrepreneurship competitions, actively organize students to participate in the "Internet +" competition, and initially establish a college student entrepreneurship plan system.

Local applied undergraduate universities require students participate in the competition to enhance students' innovative awareness and creative thinking, promote the transformation of outstanding projects, cultivate college students "Stars of Innovation and Entrepreneurship", and build a complete innovation and entrepreneurship competition education system.

\section{CONCLUSION}

As long as local applied undergraduate universities earnestly implement the guarantee mechanism of innovation and entrepreneurship education, cultivate excellent innovation and entrepreneurship teachers, and cultivate students' innovation and entrepreneurship awareness and entrepreneurial spirit, they will surely achieve the goal of innovation and entrepreneurship education and Lay a certain foundation to improve the innovation awareness and ability of the whole people.

\section{AUTHORS' CONTRIBUTIONS}

This paper is independently completed by $\mathrm{Li}$ Chen.

\section{REFERENCES}

[1] $\mathrm{Yu}$ Jie, Niu Shuzhen. Research on the problems and countermeasures of entrepreneurship education in applicationoriented private undergraduate colleges and universities $[\mathrm{J}]$. Employment of Chinese University Students, 2012 (11) 
[2] Yan Yajun, Zhu Huaixin. "Employment-based Entrepreneurship" Education for College Students-Concurrently Discuss my country's Entrepreneurship Education [J]. Jiangsu Higher Education, 2019 (3): 75-79

[3] Ye Zhengfei. Research on entrepreneurship education in local applied undergraduate universities [J]. Higher Engineering Education, 2016 (5): 53-56

[4] Zhu Jingran. Research on the construction of a diversified innovation and entrepreneurship education guarantee mechanism [J]. Journal of Hebei University of Science and Technology (Social Science Edition), 2012, (6): 102-107

[5] Ma Guanglin. Research on the Guarantee Mechanism of College Students' Innovation and Entrepreneurship Education [J]. Journal of Weifang Engineering Vocational College, 2016, (1): 5-9

[6] Wu Yunfei, Jiang Xin. Research on the construction of guarantee mechanism for innovation and entrepreneurship education in colleges and universities [J]. Inner Mongolia Science Technology and Economy, 2017, (11): 3-4

[7] Xu Wenting. The Connotation and Construction Significance of the Guarantee Mechanism of Innovation and Entrepreneurship Education in Colleges and Universities [J], Journal of Teacher Education, 2017(4): 83-87

[8] Xu Zhiqiang, Jiang Ying. Multi-dimensional research on the security system for undergraduates' entrepreneurship [J]. 2018(12): 51-54 